\title{
Redaksioneel
}

\section{Die werklikheidsbetrokkenheid van teologiese uitsprake}

\section{AG van Aarde}

In Suid-Afrika, Amerika en Europa het prof Wentzel van Huyssteen, sistematiese teoloog verbonde aan die Universiteit van Port Elizabeth, sedert die publikasie van sy boek Teologie as kritiese geloofsverantwoording: Teorievorming in die sistematiese teologie in 1986 besondere bekendheid verwerf. Die boek het veroorsaak dat verskeie bekronings gevolg het. Dit is gedurende 1987 ook aangewys as die beste wetenskaplike publikasie van 'n universiteitspersoneellid in Suid-Afrika - die natuurwetenskappe ingesluit. ' $n$ Uitgebreide oorsigartikel met betrekking tot hierdie werk is in 1987 in die Hervormde Teologiese Studies gepubliseer. In die onderhawige Aflewering word 'n resensie opgeneem van 'n ander belangwekkende publikasie van prof Van Huyssteen wat deur die Universiteit van Suid-Afrika in 1987 uitgegee is. Die titel hiervan is The realism of the text: A perspective on Biblical authority. In die lig van die belangstelling wat prof Van Huyssteen se insigte oproep, publiseer die Hervormde Teologiese Studies met die goedkeuring van die Amerikaanse vaktydskrif Modern Theology ook in hierdie uitgawe 'n voordrag van prof Van Huyssteen wat gelewer is voor die American Academy of Religion se Theology and Science Consultation op 22 November 1986 in Atlanta, Georgia. Hierdie referaat is getitel 'Evolution, knowledge and faith: Gerd Theissen and the credibility of theology'.

Gerd Theissen, met wie in die voordrag gedebatteer word, is professor in die Nuwe-Testamentiese Wetenskap en is verbonde aan die Wissenschaftlich-Theologische Seminar, Ruprechts-Karls Universiteit in Heidelberg, Wes-Duitsland. Prof Theissen het per brief op prof Van Huyssteen se bydrae kommentaar gelewer sowel as dr Helmut Reich van die Instituut vir Pedagogie aan die Universiteit van Freiburg, Switzerland. Ons gaan in hierdie redaksionele voorwoord kortliks in op ' $n$ aspek in hierdie korrespondensie. Ons vertrou dat dit sal meehelp tot die besinning oor die werklikheidsbetrokkenheid van ons teologiese uitsprake.

Theissen is van oortuiging dat die geloofwaardigheid van die Chris- 
telike geloof vandag bepaal word deur die eis dat dit nie in tradisionele vorme verduidelik moet word nie. Die vorme waarin die Christelike geloof uiteengesit word, sal moet verander ten einde te keer dat dit bloot as projeksies gesien word en illusionêr en anti-realisties van aard voorkom. Theissen beskou dus die evolusie-gedagte as 'n bruikbare kenteoretiese konsep om die Christelike geloof en dié se 'unbedingten Bindung an die Gestalt Jesu' in hedendaagse realistiese terme wetenskaplik geloofwaardig te verduidelik. Vandaar die titels van sy boeke wat in onderskeidelik 1979 en 1984 gepubliseer is: On having a critical faith en Biblical faith: An evolutionary approach.

Volgens Van Huyssteen kom die bedoeling van Theissen se 'evolusionêre paradigma' as 'n rasionaliteitsmodel, waarvolgens die teologie as wetenskap beoefen kan word, op dieselfde neer as die sogenoemde 'kritiese realisme' wat hy self as kenteorie propageer. Die kritiesrealistiese paradigma se grondslag is dat wetenskaplike uitsprake steeds op waarheidsgehalte aanspraak kan maak indien die relevansie van die uitsprake verduidelik kan word. Daar moet dus ' $n$ soort ooreenkoms bestaan tussen die realiteite waarbinne die wetenskaplike as subjek hom bevind en die uitsprake wat hy met betrekking tot sy studie-objek maak.

Die 'evolusionêre paradigma' gaan daarvan uit dat kultuur, met sy drie komponente 'wetenskap', 'kuns' en 'godsdiens', net soos in die biologiese lewe voortdurend by die veranderende werklikheid aanpas. Volgens Theissen is 'kulturele evolusie' van 'n hoër orde as 'biologiese evolusie'. Aanpassing beteken dat daar 'n verwisseling tussen die tradisionele en die nuwe plaasgevind het. Aanpassing is moontlik omdat die mens uit sy foute van die verlede leer en daarom by wyse van seleksie probleem-oplossend nuwe realiteite hanteer.

Wetenskap en geloof maak twee van die drie komponente uit waarin 'kulturele evolusie' volgens Theissen uiteenval. So gesien is wetenskap en geloof aanvullend van aard as uitdrukkinge van menslike eksistensie. Hy formuleer die dialektiek daartussen op drie maniere: wetenskaplike arbeid wat voorlopig (hipoteties) is en geloof wat dogmaties (apodeikties) is, is verskillende vorme van dieselfde aktiwiteit, naamlik die aanpassing by 'n onbekende realiteit; wetenskaplike arbeid wat deur valsifikasie gekontroleer word en geloof wat nie op feite gebaseer is nie, is verskillende vorme van omgaan met dieselfde eis wat werklikhede aan die mens stel om te selekteer; wetenskaplike arbeid wat 'n soort vreugde vind in dissensus en geloof wat afhanklik is van 
konsensus, is verskillende vorme van dieselfde openheid vir gebeure wat beslissende veranderinge meebring.

Volgens Van Huyssteen slaag die evolusionêre kenteorie nie soos die kritiese realisme daarin om epistemologies en metodologies rekening te hou met die mens se geloofsverbintenis met God en om van híer uit 'n konstante te identifiseer tussen die tradisionele en die aangepaste nuwe nie. Metaforiese spreke gebou op die Bybelse grondmetafoor dat Jesus verlos, bied vir Van Huyssteen hierdie epistemologiese en metodologiese sleutel. Godsdienstige taal het betrekking op sake wat aan die mens bekend is in verhouding met wat aan die mens onbekend is. Laasgenoemde is die terrein van goddelike misterie. Van Huyssteen meen dat die evolusionêre kenteorie nie die moontlikheid bied om bogenoemde verhouding epistemologies en metodologies te eksploiteer in terme van die basiese vraag rakende die werklikheidsbetrokkenheid van teologiese uitsprake oor geloof nie. Hiervoor is dit in elk geval nodig om tussen geloof as sodanig en teologiese uitsprake oor geloof te onderskei. Theissen vermeng volgens Van Huyssteen paradigmas.

In sy reaksie op Van Huyssteen skryf Theissen (briefwisseling, 27 April 1987) dat hy nie verstaan waarom Van Huyssteen so 'n radikale onderskeid tussen die evolusionêre kenteorie en die krities-realistiese paradigma wil tref nie. Op grond van Theissen se reaksie blyk dit dat Van Huyssteen nog nie sy boodskap helder tuisgebring het met betrekking tot die epistemologiese en metodologiese implikasies van die feit dat godsdienstige ervaring en ons teologiese uitsprake daaroor die fisiese lewe transendeer nie. Dit is nie duidelik genoeg waarom 'n rasionaliteitsmodel wat op die biologiese lewe toepasbaar is, nie vir die teologie met sy 'simboliese karakter' kan geld nie. Theissen sê dat hy wel insig het in Van Huyssteen se beswaar dat die evolusionêre paradigma in grondliggende spanning verkeer met geloof wat op 'n onvoorwaardelike verbintenis neerkom. Dit is met ander woorde die vraag of die mutasieproses wat in byvoorbeeld die biologiese lewe voorkom, vergelykbaar is met die beslissende veranderinge in die werklikheid wat ook mense meemaak wat onvoorwaardelik aan die Jesus-saak gebind wil bly. Bly die evolusionêre paradigma nie bloot by teoretiese denke sodat dit juis nie 'n bydrae lewer tot die werklikheidsbetrokkenheid van dié geloofsverbintenis nie? Theissen sê wat hy in die oog het, is 'n kenteoretiese weg wat tussen die fundamentalistiese Bybelse literalisme en fiksionalisme beweeg. Hy beoog, ons insiens, dus dieselfde as die relasionele waarheidsbegrip wat Van Huyssteen 
voorstaan en wat 'n objektiwistiese sowel as 'n subjektiwistiese waarheidsbegrip onaanvaarbaar vind.

Die rol wat Van Huyssteen metafore in die teologie wil laat vervul, is inderdaad ' $n$ sinvolle wyse waarop metodologies uitdrukking gegee kan word aan die relasionele waarheidsbegrip. Daar bestaan uiteraard ook ander metodes om dieselfde kennisweg te onderneem. Een van die belangrike konsekwensies van die klem wat op metafore in die teologie gelê word, is die metodologiese moontlikheid wat dit bied om met die pluraliteit van Bybelse getuienis en kerklike konfessies rekening te hou. Dit is juis in die lig hiervan dat interdissiplinêre spanwerk tussen Bybelwetenskaplikes en sistematiese teoloë 'n opwindende moontlikheid word. Ons insiens kan Van Huyssteen se basis, naamlik om metodologies te opereer vanaf die grondmetafoor 'Jesus verlos', egter kontra-produktief wees. Dit is debatteerbaar of hierdie formule in die grond van die saak reg laat geskied aan die pluraliteit van die veelgeskakeerde Christus-kerugmas van die baie Bybelskrywers as eksponente van die vele strominge in die vroegste kerk - om nie eens te praat van die aardse Jesus self nie. Dit is buitendien ' $n$ vraag of bogenoemde formule as 'n 'metafoor' getipeer kan word.

Die hantering van die dialektiek tussen 'dissensus' en 'konsensus' deur Theissen moet ons insiens nie as irrelevant beskou word nie. Volgens Theissen het die vroeë kerk drie kontroles ingebou om dié dialektiek te beskerm, naamlik die kanon, die regula fidei en die episkopaat. Van Huyssteen toon hiermee instemming. Tog beskou hy dit met die oog op kritiese realisme as irrelevant. Hierdie drie sake lê volgens hom eerder op die vlak van geloof as sodanig en nie op die rasionaliteitsvlak waar die teologie as uitsprake oor geloof hom bevind nie. Van Huyssteen oortuig ons egter nie in hierdie verband nie. Waarom kan bogenoemde drie konsepte nie as deel van die vroegste herinterpretasie van die Jesus-saak (waarvan ons die 'grondmetafoor' met behulp van 'n ander formule sou wou voorstel) gesien word nie? Dit is ons insiens deel van die tradisionele model wat sowel die Nuwe Testament as die kerklike konfessies bied en wat hermeneuties in konstruktiewe teologie probleem-oplossend benut behoort te word sodat die Jesus-saak in veranderende realiteite metafories nuut geïnterpreteer kan word. Bogenoemde drie konsepte is basiese wyses waarop daar in die Nuwe Testament sinvol gepraat is oor die 'weg' wat die Jesus-saak tot die 'realiteit van God' bied.

Dr Helmut Reich het in sy reaksie op Van Huyssteen se 'kontrovers' met Theissen (briefwisseling, 27 Mei 1987) onder andere ook aangesluit 
by die rol wat die Bybel in die teologie moet vervul. Die onderskeid wat Van Huyssteen tussen enersyds geloof as sodanig en geloof as geleef (fides qua) en andersyds teologiese uitsprake maak, is vir hom problematies. Wetenskap en geloof kan nie so radikaal van mekaar geskei word asof dit verskillend verwys nie. As pedagoog ervaar hy dat studente koherensie in hierdie verband verlang.

Ons insiens is die onderskeid wat Van Huyssteen maak, wel belangrik. Hy moet egter nie iets wat hy goed besef, uit die oog verloor nie. Dit is naamlik dat die geloofservaringe van Bybelse persoonlikhede uit die Bybel geabstraheer moet word en nie die voorhandene is nie. Wat die Bybel op sigself bied, is alreeds uitsprake oor mense se geloofsverbintenisse met God. Bybelse getuienis is reeds metaforiese getuienis. Konstruktiewe teologie moet om krities werklikheidsbetrokke te wees, aan die hand van die tradisionele model, in die Nuwe Testament gegewe, die geloofsverbintenis van mense hier en nou dien. Wetenskaplike teologie is hiervoor onontbeerlik en ook die Nuwe-Testamentiese wetenskap. Gaan 'n mens nie van die regte 'grondmetafoor' uit nie, word die Nuwe Testament egter alte gou verlaat en kan die teologie weer skolastiese sisteem-denke rondom dié teoretiese 'grondmetafoor' word. En wat word dan van die spanwerk waarna ons hierbo verwys het?

Die belangrike vraag wat Reich in hierdie verband aanraak, is dié rakende die geloofwaardigheid van die teologie wat Bybelse metafore werklikheidsbetrokke wil maak in terme van hedendaagse lewenskontingensies. Reich verwys na die teologie van bevryding, oorlewering binne politieke totalitarisme ensovoorts as voorbeelde van sulke kontingensies. Kan die Bybel as sodanig hierby überhaupt betrokke wees?

Die antwoord op hierdie vraag hang af van die wyse waarop die Jesus-saak waaroor die Nuwe Testament verskillend getuig, beskryf en nuut verkondig word. Die identifisering van 'n menslike geloofwaardige 'grondmetafoor' is van wesenlike belang. Ons is steeds daarvan oortuig dat die Jesus-saak vandag probleem-oplossend in die werklikheid betrokke kan wees. Maar dan sou ons dié saak op die kortste moontlike manier soos volg formuleer: Jesus het die verwagting realiseerbaar gemaak dat waaragtige lewe in diens van die teenwoordige God moontlik is, en wel deur lyding en dood heen. 